\title{
The Zombie Phenomenon in Banking and Business: a Comparative Analysis and the Origin of the Institutional Problem
}

\author{
Ihor Hurnyak \\ Ph.D., Ivan Franko National University of Lviv, Faculty of International Relations \\ Lviv, Ukraine, e-mail: ag.kpl.Iviv@gmail.com
}

\author{
Aleksandra Kordonska \\ Ph.D., University of Warmia and Mazury in Olsztyn, Institute of Political Science \\ Olsztyn, Poland, e-mail: alexandra.kordonska@gmail.com
}

\begin{abstract}
The research presents an investigation of the zombie phenomenon in banking and business. The main goals are as follows: to reveal the consequences of the threatening dynamics of nonperforming loans for the states of Central and Eastern Europe, Western Europe, the group of former USSR states, and Latin America; to demonstrate the zombie business phenomenon in the case of Ukraine and disclose a new form of zombie business on the basis of different tools with exception of banking loans. The authors believe the solution to the zombie banks problem will not be found in the growth of government influence or control but in the restructuring of the banking system based on a decentralized but strongly controlled bottom-up model. The ineffectiveness of the institutional system also generates various forms of zombie business. The case of Ukraine is the best illustration of applying the tools, that are used in zombie business, with the exception of banking loans. The article helps to understand the influence of nonperforming loans on the economy and the perspectives for banking system formation in the light of the institutional aspect and interinstitutional interactions with the active participation of NPLs.
\end{abstract}

Keywords: bank system, banking, zombie banks, zombie business, nonperforming loans, institutional theory

JEL: D02, F34 


\section{Introduction}

The problem of zombie banks occurring in the modern economy is a result of the strong growth of nonperforming loans - a unique indicator of the financial health of the banking system. This can be traced on the basis of the phenomenon and its consequences. According to Stephen Bush (2018), commercial banking and business consulting expert, the practice of zombie banks lives on. There are many banking institutions that are effectively bankrupt but are being kept in business through artificial government supports and guarantees. The expert notes that in some cases, these banks are being kept on a short leash and in others, they are operating with more flexibility, but they are certainly not lending normally. In the expert's opinion, the failure of these banks to operate like "real banks" is a major contributing factor in explaining why the economy and real estate, in particular, are still functioning as if they are on life support in many areas. The other phenomenon is zombie businesses, meaning firms that are unable to cover debt servicing costs from current profits over an extended period. This problem has also recently attracted increasing attention in both academic and policy fields.

In our research, we would like to focus on a comparative analysis of the influence of nonperforming loans (NPLs) on the economy, and the main directions of their use in Central and Eastern Europe, Western Europe, and Latin America. We would also like to propose perspectives for the formation of the banking system in light of the institutional aspect and the interinstitutional interactions with the active participation of NPLs. Apart from this, we would like to demonstrate the zombie business phenomenon in the case of Ukraine and show new forms of zombie business based on different tools, with the exception of banking loans. On the basis of the analysis, an institutional way of solving this problem is proposed.

The methodological basis for the research is both economic and statistical methods. The research contains zombie banking performance (estimated as bank non-performing loans to total gross loans (\%)) in Japan, China, South Korea, Singapore, the EU states, Central and Eastern Europe, and Ukraine between 2008 and 2017. The influence of NPLs on particular economic indicators is presented by a model of linear regression in Central and Eastern Europe, Western Europe, a group of post-communist states, and Latin America. An investigation of zombie businesses in the case of Ukraine based on non-bank debt is made by a logistic regression mechanism and game theory tools. To do this, we consider the interaction of zombie structures based on traditional and manipulative strategies. The Nash equilibrium allows us to describe the current steady state of such an economy. 


\section{Zombie banking. The origin of the institutional problem}

According to Stephen Bush (2018), the term "zombie bank" first appeared more than 25 years ago when the savings and loan crisis in the United States resulted in hundreds of financial institutions having liabilities in excess of their assets. The political response was a variation of "Too Many to Fail," and Zombie Banks were born.

A zombie bank is an insolvent financial institution that operates mostly thanks to implicit government support. Zombie banks have large amounts of nonperforming assets on their balance sheets (Investopedia 2018). Under legislation regulating banking activities, banks must bear all underlying losses when a loan becomes non-performing. Nonetheless, some banks are unwilling or financially unable to recognize loss trends, or they overvalue bad loans by arguing that they will recover the sum borrowed in the long run. Such solutions often transform these banks into "zombies." Zombie banks are creatures of financial repression, in which central banks keep debt-burdened banks, corporations, and households on life support, instead of allowing nature to take its course and creative destruction to do its work (Investopedia 2018). "Zombies" are banks that administrate such bad loans instead of offering new loans, losing its system-making role in the economy. Consequently, the circulatory system of the economy remains without a decisive component. Granting new loans is also restricted by the shortage of own capital as banks are forced to set aside a larger share of capital to cover the potential losses generated by bad loans (Markevičius 2017).

The financial and banking crisis in Japan in the late 1990s and early 2000s has attracted the interest of researchers on the specific subject of forbearance lending by commercial banks. Japan is the first well-documented case of zombie banking in a developed economy. Apart from this, Japan also contributes an interesting case with regard to the policy measures against zombie banks. The Japanese central bank has shifted to a zero interest rate policy, while the government has applied a wide range of measures, including equity injections, blanket guarantees, and asset transfers through bad banks. A detailed account of the course of events around the financial crisis, including the policy measures is provided by Nakaso (2001), Kanaya \& Woo (2000) and Kawai (2005).

The sovereign debt and banking crisis in Europe shares many similarities with the situation in Japan, as outlined by Schnabl (2013). The study of Willam (2015) demonstrates the example of Japan and Europe as a case study of zombie-bank experience. Japan, for example, chose the approach of gradual recovery, tolerating the negative effects of zombie banking in order to reinstate bank health. In Europe, the policy was even more accommodative than in Japan.

Schoenmaker \& Peek (2014) studied the 30 largest banks in Europe by analyzing balance sheets for the market capitalization for each bank. They assumed either a 3\% or 5\% threshold ratio of market capitalization over total assets for each bank and determined that the capital shortage for those banks comes to 84 billion and 365 billion EUR respectively. In their next study, they simulated a financial crisis and calculated what the capital shortfall would then be for a $3 \%$ ratio, which comes to 241 Euro. Similar research was 
done by Acharya and Steffen (2014), who ran a stress-test for 124 banks in the Euro-area that are subject to the supervision by ECB from 2014 onwards. Such studies could show how much capital banks would need if another financial crisis broke out.

Radivojevic \& Jovovic (2017) carried out a deep panel data analysis despite detecting a relationship between the macro- and micro-environment related to NPLs. The basis for their analysis was the results of the panel regression during the period 2000-2011. They examined the determinants of the NPL ratio using a cross-country analysis from a sample of 25 emerging countries. The results showed a negative and significant relationship between GDP and the rate of NPLs.

As noted by Mora (2017), the EU has developed harmonized definitions for NPLs and emphasized the need for restriction - 90 days for defaulted exposures. He also highlights supply-side and demand-side impediments. Supply-side impediments include an unwillingness to realize losses, the high cost of debt recovery not recognized in NPL book values, accounting and tax rules regarding NPLs, etc. Demand-side impediments include information asymmetry (the lemons problem) revealed in the unavailability of sufficient and reliable data on NPLs, barriers to entry to the EU secondary NPL market for investors represented in licensing and other compliance requirements, long and complicated debt enforcement processes, legal barriers to transferring loans to a new creditor, etc. To solve this problem in the Czech Republic, he proposed improving the legislative framework, to enable better collateral enforcement and debt collection and to decrease the average duration of litigation.

\section{"Zombie banking" performance}

Researchers use different indicators to measure banks' lending activities, but the most commonly used indicators to identify credit risk are non-performing loans to total loans (NPLs) and loan loss provision to total loans (LLP). Figures 1 and 2 present zombie banking performance in Japan, China, South Korea, Singapore (Figure 1) and EU states (Figure 2) between 2008 and 2017. As we can observe, the recent situation in the Asian region related to bad loans is fairly positive, while the Euro region is struggling with post-crisis challenges. Considering more specific challenges that euro area banks are facing in the post-crisis environment, we should underline the low profitability environment banks operate in, the structural challenges related to overcapacity in some banking markets, and the large number of NPLs.

According to Vice-President of the ECB, Vítor Constâncio (2016), a key challenge for European banks is linked to the prolonged period of low profitability in the sector. While bank profitability has recovered somewhat recently, it remains at very low levels. Considering the World Bank data, the average Return on Equity (ROE) of the major banks in the Euro area was 5.8\% in 2015, remaining below their cost of capital (estimated to be around 9\%). In fact, the negative gap between banks' ROE and the cost of equity has persisted since the 2008 financial crisis. 
The Zombie Phenomenon in Banking and Business: a Comparative Analysis...

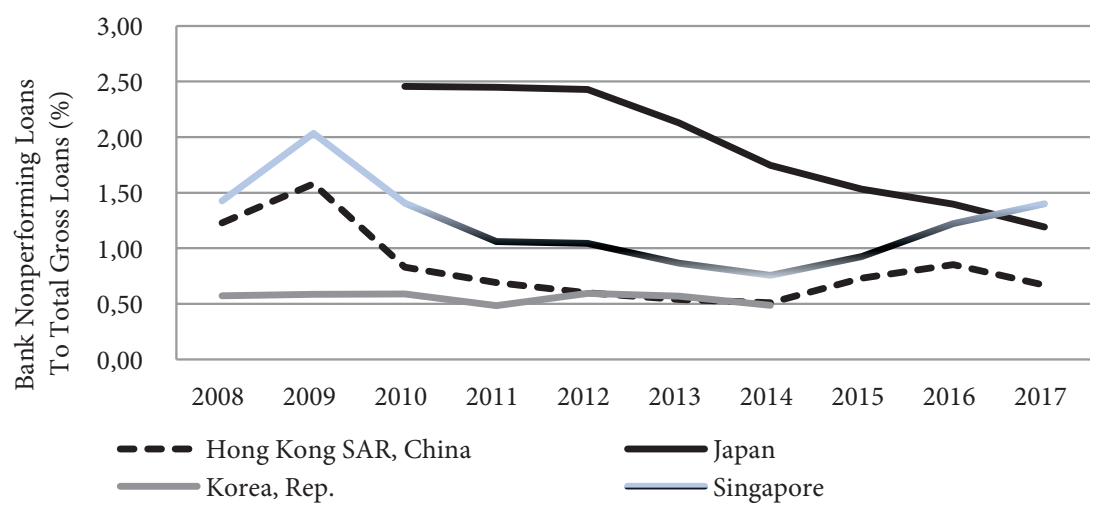

Figure 1. Japan's "zombie banking" performance in comparison to China, South Korea, and Singapore, 2008-2017

Source: authors' own elaboration on the basis of World Bank data.

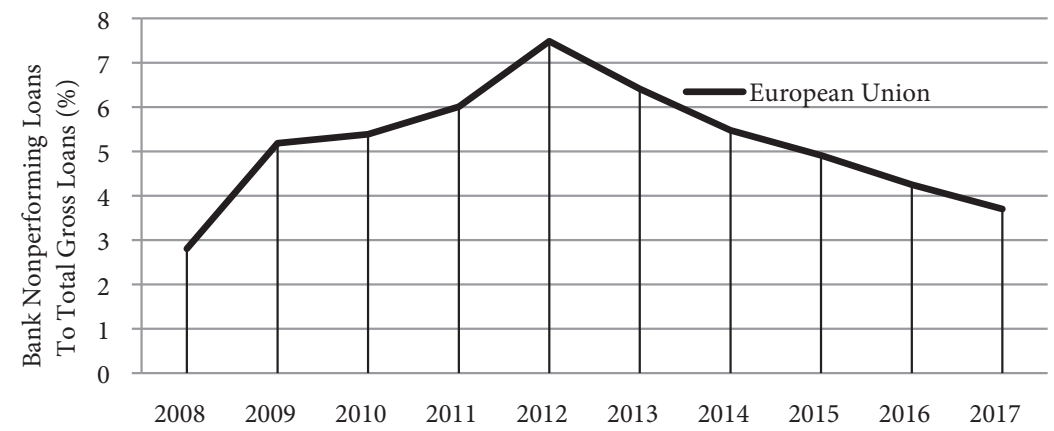

Figure 2. The EU's "zombie banking" performance, 2008-2017

Source: authors' own elaboration on the basis of World Bank data.

The presence of high NPLs has a significant impact on banks' profitability, as a great part of their assets do not generate revenue. Significant institutions in the Euro area held nearly EUR 950 billion of nonperforming loans at the end of 2015, equivalent to about $9 \%$ of euro-area GDP. Their average NPL ratio, at 7.1\%, is high by international standards and clearly exceeds those of their US and UK peers. NPL ratios vary widely across the euro area but remain at somewhat elevated levels in the majority of countries that were most affected by the financial crisis (Constâncio 2016).

Furthermore, by introducing the banking situation on the European continent, we would like to draw attention to some countries of Central and Eastern Europe. Figure 3 presents the "zombie banking" performance in the Czech Republic, Hungary, Lithuania, Moldova, Poland, Russia, Slovakia, Slovenia, and Ukraine. The majority of these states are characterized by bad loans at a level under $10 \%$ of total gross loans in 2017. Moldova reached 20\%, while Ukraine - more than $50 \%$. 


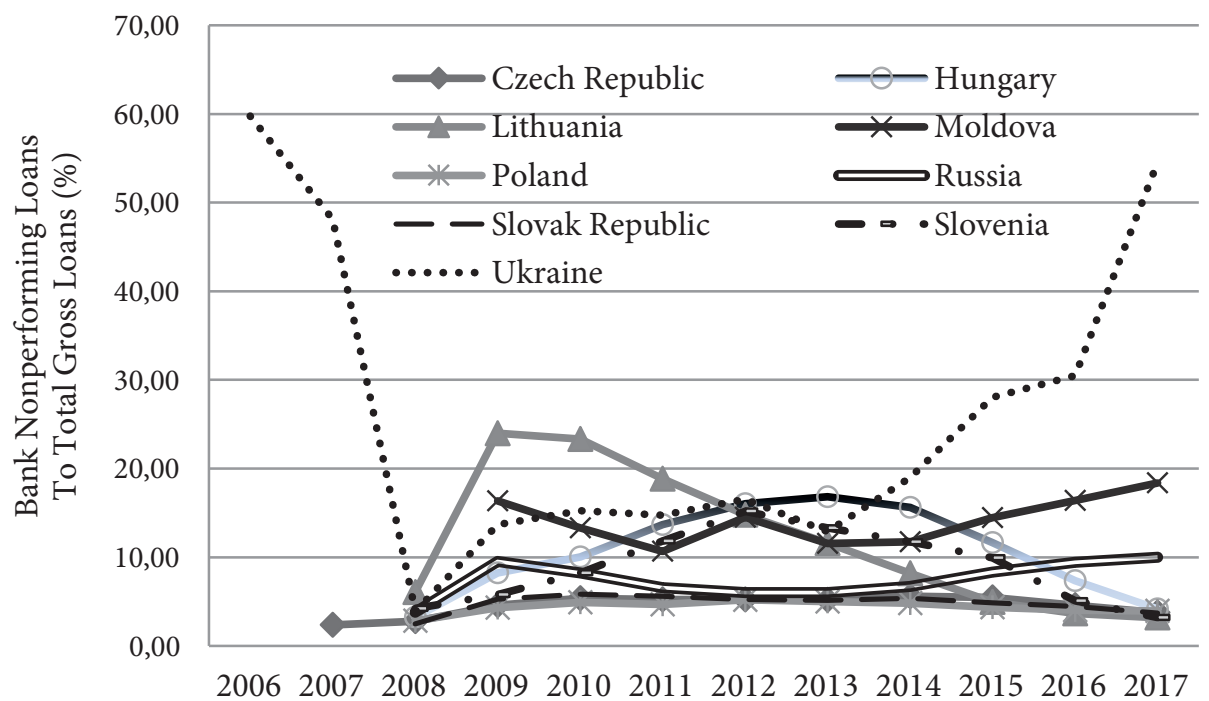

Figure 3. Ukraine's "zombie banking" performance in comparison to neighboring states, 2008-2017 Note: Ukraine's Non-Performing Loans Ratio was 54.5\% in December 2017, compared with the ratio of $56.4 \%$ in the previous quarter. The data reached an all-time high of 59.8\% in December 2006 and a record low of $2.7 \%$ in March 2008 (The Global Economy).

Source: authors' own elaboration on the basis of World Bank data.

Over the past year, the Ukrainian Deposit Guarantee Fund, along with the National Bank, has unsuccessfully run a pilot project to sell assets for "bad loans" through American sources with the help of foreign brokers with extensive experience. Since the auctions did not work as expected, the problem of nonperforming loans needs to be addressed, starting with the corporate portfolio. There is about 255 billion UAH in loans, $97 \%$ of which are issued to 40 companies. These companies are large industrial groups which today not only have significant debts but are also, in fact, the owners of the Deposit Guarantee Fund. Some of the beneficiaries of these companies have banks in Ukraine. They challenge loan agreements in courts and then receive a decision giving them 25 years to restructure their debts. Under such circumstances, it is easy to predict that in the absolute majority of cases there is no longer any incentive to carry out the restructuring. In 2009, the Guarantee Fund was engaged only in payments. The interim administrations, as well as the liquidation of banks, were under the competence of the National Bank. It was expected that a bad bank (in other words, a hospital bank) would be created to isolate illiquid and high-risk assets. However, despite years of intensive work of this institution, nothing was sold. It is obvious that under the condition of stimulating financial health, the banking system performs its functions only conditionally. According to the data of the Ukrainian Financial Forum, in 2013 less than 14\% of small businesses in Ukraine used bank credit. 


\section{Banking system perspectives: the institutional aspect}

Is there a general solution to the NPL-problem? Are the consequences of the long-term absence of this problem identical? We shall try to investigate the problem based on the nature of its occurrence as well as the main interinstitutional interactions with the active participation of NPLs.

Considering the dangers for the economic environment, such as offshore banking and nonperforming loans, particular attention should be paid to the basic banking background, such as the bank model, centralization/decentralization processes in the banking system, the decision-making model inside the bank, the bank institution as such, etc. The authors of the article are convinced that the solution to the earlier discussed problem should be sought in the reorganization of existing banking institutions, and in the case of EU member states - a return to the initial proven practice of a decentralized, three-pillar banking system.

For over 25 years, and perhaps in the broader context of more than two centuries, the European banking system (by applying the term "world banking system," it could include the American experience) is based on three pillars: private banks, public (savings banks) and mutual (cooperative) banks. The most interesting experience could be that of Germany. The experience of German savings and co-operative banks is unique since they have preserved both the "purity" of the model and most of its traditional functions, i.e., they have abandoned the transformation towards a "shareholder-oriented bank." The processes of deregulation, liberalization, and privatization changed the forms of all these banks; moreover, an attempt was made to portray these institutions as old-fashioned, outdated and ineffective. At the same time, there are initiatives to extend the behavior model of savings and co-operative banks to joint-stock companies. That is, the discussion focuses on the "business model" and "institutional features."

From the perspective of post-crisis Europe, there are two common features of savings banks: (1) a focus on savings and mobilizing savings and (2) a focus on the regional or even local level. However, this identification refers to the prevailing systems that have undergone a long process of transformation and harmonization. When considering Eastern European states, like Ukraine, it seems appropriate to use the experience of approximately 25 years ago, with the following list of key features identifying the institution of a savings bank (Bülbül, Schmidt \& Schüwer 2013):

- Ownership, sponsorship, or management by the relevant public authority.

- Organization within the framework of public law.

- The public purpose is to support the local economy and, at the same time, act in accordance with the general business rules, to stay financially sustainable.

- Adherence to the "regional principle" - limiting the operations of a savings bank to areas under the public authorities' responsibility. Such banks consider each other to be colleagues, not competitors.

- Banks constitute a cooperative network of legally independent institutions. Therefore, the scale economy becomes the prerogative of the network as a whole. 
If, in the recent past, this set of features made it possible to distinguish savings banks from everyone else, now in most countries, this system has become a distant prototype.

Most co-operative banks are largely resilient to savings. They follow a "regional principle" and work as part of a complex network that facilitates internal co-operation. Their scope is to support the economic efforts of their clients while remaining a profitable business. The main difference between a cooperative bank and other banks is their legal basis. There are three principles for the formation of the institutional structure of financial and other cooperatives:

- They are self-governing private organizations.

- Their members are mainly clients and vice versa. Many customers are both clients and members.

- Each member has only one vote at the annual general meeting, regardless of the size of his share. Members cannot sell their shares if they want to leave. They can return their shares to the cooperative to get what they invested at the beginning, with a share of the accumulated profit. Some analysts state that because of such principle the incentives are weak, since it is impossible to resell their share at a higher price, and there can be no pressure on management since it is impossible to accumulate votes. We disagree with this thesis since there are effective forms of collective decision-making and collective action in relation to part of the assets, which is described in detail in the research of Ostrom (1990).

Consequently, the German models of the savings and co-operative bank have become prototypes for other European countries. In Germany today, local savings banks, land banks, and associations form a dense network of institutions. Local banks remained the basis of this banking group. In 2001, the German government agreed with the European Commission on the gradual abandonment of having savings and land banks under state guarantees. This has had serious implications for land banks, but local savings banks have easily dealt with this change. Such banks are mainly funded by individuals' deposits, and there is a powerful internal control system. In addition, security operations had a good basis because of the concentration on operations in a well-studied local market. The focus on local interest is the best auditor for the banking institution. Cooperative banks have become a stabilizing instrument or mechanism for the entire banking system in a crisis (Henselmann, Ditter \& Lupp 2016).

The problem of bank debt can be solved in two ways. The first path is an increase of control and involvement of the state. For example, in the United States, the Sarbanes Oxley Act (2002) was adopted to address the problem of the poor quality audit of large companies and to introduce a wide range of additional reports. The second way is less costly and more market-friendly. It is based on restructuring the banking system, transforming it into a more accessible and more controlled institution for citizens and communities. Obviously, such banks are becoming much weaker players in the market of derivatives or bonds, but they are starting to work for the real sector of the economy. 


\section{A comparative analysis of the influence of nonperforming loans on the economy in Central and Eastern Europe, Western Europe and Latin America}

The problem of NPLs in banking does not have any geographic exclusivity and can be observed in every economy of the world. At the same time, there is a divergence in the consequences of tolerance. We want to demonstrate the influence of NPLs on particular economies by using a model of linear regression.

Considering the influence of NPLs on economic growth in Europe, including post-communist states (Table 1), we can state the negative influence of nonperforming loans on GDP growth. As we can also observe, this negative influence (of the amount of unpaid debt of such a banking system on the economic processes) is quite weak (with a correlation coefficient of -0.153). Such results could be explained by a too diversified sample of research, an insignificant share of long-term contracts (as too small resources are accumulated in the banking sector), the technological backwardness of production and equipment, as well as the problem of withdrawing capital abroad.

Table 1. The influence of NPLs on economic indicators in Central and Eastern Europe and a group of post-communist states

\begin{tabular}{|l|c|c|c|}
\hline & NPL & R_D_GDP & GDP_D \\
\hline NPL & 1 & $\begin{array}{c}-0.076 \\
(0.335 .163)\end{array}$ & $\begin{array}{c}-0.153 \\
(0.020 ; 228)\end{array}$ \\
\hline R_D_GDP & & 1 & -0.030 \\
& $-0.076^{* *}$ & $(0.642 ; 237)$ \\
\hline GDP_D & $\left.-0.1535^{* * *} .163^{* * * *}\right)$ & -0.030 & 1 \\
& $(0.020 ; 228)$ & $(0.642 ; 237)$ & \\
\hline
\end{tabular}

Notes: NPL - nonperforming loans in Central and Eastern Europe and a group of post-communist states; R_D_GDP - percentage ratio R\&D/GDP; GDP_D - percentage change of GDP; ** - Pearson Correlation; ${ }^{* * *}$ - significance; ${ }^{* * * *}$ - number of observations

Source: authors' own research.

Furthermore, the compression of the data sample in Table 2 in Central and Eastern Europe (including all states from the Federal Republic of Germany to the Russian Federation border) show a negative impact of NPLs on export flows (-0.132 (0.093; 162)). Such a negative influence can be explained by the significant role of banking for export support (like the KUKE export agency in Poland) under the conditions of the export orientation of the majority of the identified economies. The other reason is the prevalence of integrated transnational corporations in Central and Eastern Europe and therefore, the use of long-term contracts, the possibility of irregular investment, etc. At the same time, with lower statistical significance, we can observe a weak negative influence of NPLs on GDP growth. 
Table 2. NPL Influence on economic indicators in Central and Eastern Europe

\begin{tabular}{|l|c|c|c|c|c|}
\hline & R_D_GDP & NPL_CEU & IMPORT_D & GDP_D & EXPORT_D \\
\hline R_D_GDP & 1 & $\begin{array}{c}0.015^{* *} \\
\left(0.86^{* *} ;\right. \\
128^{* * * *}\end{array}$ & $\begin{array}{c}-0.018 \\
(0.81 ; 166)\end{array}$ & $\begin{array}{c}-0.115 \\
(0.13 ; 167)\end{array}$ & $\begin{array}{c}-0.077 \\
(0.3 ; 166)\end{array}$ \\
\hline NPL_CEU & 0.015 & 1 & -0.022 & -0.118 & -0.132 \\
& $(0.867 ; 128)$ & & $(0.78 ; 162)$ & $(0.13 ; 165)$ & $(0.093 ; 162)$ \\
\hline
\end{tabular}

Notes: NPL_CEU - nonperforming loans in Central and Eastern Europe; R_D_GDP - percentage ratio R\&D/GDP; GDP_D - percentage change of GDP; IMPORT_D - percentage change of import; EXPORT_D - percentage change of export; ${ }^{* *}$ - Pearson Correlation; ${ }^{* * *}$ - significance; ${ }^{* * * *}$ - number of observations

Source: authors' own research.

The analysis of the influence of nonperforming loans on Western European economies (Table 3), as in previous studies, shows quite a weak, negative correlation between NPLs and the percentage change of GDP $(-0.102(0.179 ; 177))$. Despite the fact that unpaid loans show no significant impact (a time lag was not considered in this article) on import flows and economic growth, their impact on the economy as a whole is evident, as a negative correlation exists with the share of research and development indicator/GDP $(-0.47(0.00 ; 134))$. About a trillion of such debts in EU banks means that the prospects of the economy withstanding competition in the future are significantly reduced. On the other hand, it is likely that this debt was created to support exports, as shown by the positive correlation of indicators. We did not see such a phenomenon in any of other considered region. It also reflects the nature of the economies being considered. The results of the presented correlation on nonperforming loans and investment in R\&D in Western Europe confirm that such a banking system differs favorably from all other worldwide approaches.

Table 3. The influence of NPLS on economic indicators in Western Europe

\begin{tabular}{|l|c|c|c|c|c|}
\hline & R_D_GDP & NPL_WE & IMPORT_D & GDP_D_WE & EXPORT_D \\
\hline R_D_GDP & 1 & -0.47 & 0.004 & 0.104 & -0.11 \\
& & $(0.00 ; 134)$ & $(0.95 ; 169)$ & $(0.17 ; 169)$ & $(0.88 ; 169)$ \\
\hline NPL_WE & -0.47 & 1 & -0.031 & -0.102 & 0.166 \\
& $(0.00 ; 134)$ & & $(0.68 ; 177)$ & $(0.179 ; 177)$ & $(0.039 ; 155)$ \\
\hline
\end{tabular}

Notes: this table uses the same order of variables as in the previous one; NPL_WE - nonperforming loans in Western Europe; GDP_D_WE - percentage change of GDP in Western Europe

Source: authors' own research.

For comparison, we would like to consider Latin American countries (Table 4). According to the obtained results, we can also confirm the impact of nonperforming loans on the economy in this region, which is even more significant than in the case of Europe. Here, the negative dynamics of the nonperforming loans hurt export/import flows, as well as economic growth. Somewhat unexpectedly, it can be an indicator of either positive or negative phenomena for the economy. On the one hand, this means 
that the banking system is an integral part of the economic system as a whole, and its imbalance immediately causes a reaction in the whole system. It is possible to recover such a banking system (we can see the diametrically opposite situation in Ukraine, where such interconnection is not observed). Despite this, this institute is a threat to the functioning of the economy as a whole. At the same time, there is not expected to be an interaction with the share of investment in research and development.

Table 4. The influence of NPLs on the economy in Latin America

\begin{tabular}{|l|c|c|c|c|c|}
\hline & R_D_GDP & EXPORT_D & IMPORT_D & NPL_LA & GDP_D \\
\hline R_D_GDP & 1 & -0.095 & 0.069 & 0.197 & -0.132 \\
& & $(0.47 ; 60)$ & $(0.6 ; 60)$ & $(0.139 ; 60)$ & $(0.313 ; 60)$ \\
\hline NPL_LA & 0.197 & -0.162 & -0.281 & 1 & -0.182 \\
& $(0.139 ; 58)$ & $(0.12 ; 94)$ & $(0.006 ; 94)$ & & $(0.079 ; 94)$ \\
\hline
\end{tabular}

Notes: this table contains the same order of variables as in the previous one; NPL_LA - nonperforming loans in Latin America

Source: authors' own research.

Consequently, we can focus on the following results. If, in the case of Eastern Europe, the banking system generally is a supporter of export promotion and economic growth (Tables 1 and 2, respectively), then in the case of Western Europe, the main scope of the banking sector is to ensure technological growth and export support (Table 3). In the Latin America region, the influence of the banking sector on export-import flows, as well as the economy as a whole, is even more significant than in European countries (Table 4).

\section{Zombie business: the case of Ukraine}

What is a zombie company? It is a listed firm, with ten years or more of existence, where the ratio of EBIT relative to interest expenses is lower than one. In essence, as was shown by Lacalle (2017), a company that merely survives due to the constant refinancing of its debt and, despite re-structuring and low rates, is still unable to cover its interest expense with operating profits, let alone repay the principal. The focus on listed companies allows us to consider two different ways of identifying zombie firms: a broad measure proposed by McGowan (2017), based on the persistent lack of profitability in mature firms; and a narrow one proposed by Banerjee (2018) and Hofmann (2017), which additionally requires expectations of low future profitability inferred from a firm's stock market valuation.

Banerjee (2018) highlights the following key points: "The prevalence of zombie firms has ratcheted up since the late 1980s. This appears to be linked to reduced financial pressure, reflecting in part the effects of lower interest rates. Zombie firms are less productive and crowd out investment in and employment at more productive firms. When identifying zombie firms, it appears to be important to take into account expected future profitability in addition to weak past performance." 
Banerjee's research shows many negative interactions between zombie and non-zombie companies. "[The] estimation results suggest that a 1 percentage point increase in the narrow zombie share in a sector lowers the capital expenditure (capex) rate of non-zombie firms by around 1 percentage point, a $17 \%$ reduction relative to the mean investment rate. Similarly, employment growth is 0.26 percentage points lower, an $8 \%$ reduction" (Banerjee 2018).

Quiggin considers the consequences for the economy as a whole after the return of such components to common functioning. "Translating to the real world question, if we observe one set of children born into a wealthy family, with parents willing and able to provide high quality schooling and 'legacy' admission to the Ivy League universities they attended, and another set, whose parents struggled to put food on the table, we should not be concerned that members of the first group almost invariably do better. After all, some people from very disadvantaged backgrounds achieve success, and there was no law preventing the rest from doing so" (Quiggin 2012).

At the same time, the use of profitability indicators encounters many institutional and technological problems. It is easier to manipulate earnings compared to operating cash flow. For example, there are many potential manipulative steps that use depreciation methods, that allow bad debt and write-offs, acquisitions, or that allow equity methods, etc. Excessive attention is paid to profitability, but it is, in fact, the result of the accountant's proficiency. That is why, in the practice of financial analysis, we use the ratio of operating cash flow to interest rate, taxes, and operating income. Such analysis aims to compare this ratio with "1", and in case of closeness, to reject the suspicion about potential manipulation.

That is why we have tried to find an additional approach to identify zombie firms. We shall focus on the case of Ukraine. The share of non-performing loans in the total volume of bank loans in Ukraine in May 2018 decreased to 56.09\% from 56.18\%, according to the National Bank of Ukraine (NBU). The share of NPLs in PrivatBank (the most significant example of a zombie bank in Ukraine) fell slightly, to $85.07 \%$ from $85.41 \%$; in other state-owned banks it fell analogically - to $60.14 \%$ from $60.3 \%$; in banks of foreign banking groups - to $42.83 \%$ from $42.94 \%$; while in banks with private capital, it grew to $25.38 \%$ from $24.79 \%$ (Ministry of Finance of Ukraine 2018). In the case of financial analysis, we should eliminate the influence of associated structures on the profitability of an appraiser. However, in the case of Ukraine, we are talking about lending within the financial group, when the owner of the bank and the recipient of the loan are associates. It means that most Ukrainian businesses do not have access to credit, but at the same time, it is still necessary for them to look for opportunities for competitiveness on the market.

An unexpected case in Ukrainian practice is that for many businesses, it makes no sense to hide profits by using accounting methods. Such firms work only partially in the official economy. For this official part of their business, long-term negative financial results have no traditional consequence, e.g., bankruptcy. It is assumed that such firms do not pay income tax (there is no sense hiding this fact since there 
are no official consequences) and they look for additional financial resources aimed at increasing accounts payables, for example, salaries payable, insurance payable, tax payable, advances payable, etc. In this way, such businesses try to compete with those of a "high level," which can function as traditional zombie businesses in the framework of a not transparent bank refinance system and an expanded Ponzi scheme with state treasury bills.

That is why we would like to study business debt practice in Ukraine by taking into account institutional aspects. The basis for our study is 70 observations in the form of balance sheets and income statements of selected enterprises. Among them are those which maintain a negative value of retained earnings for more than two years, and those which do not support such practices and use mainly a range of commonly known accounting tools. It is worth noting that the factual absence of a bankruptcy procedure in Ukraine (or its imitative, theoretical nature) makes it possible for both these types of enterprises to function. Moreover, as in reality, an enterprise which is going through bankruptcy proceedings could still hold shareholders' meetings, change its organizational and legal form, carry out business operations, win tenders, and so on. At the same time, there remains the possibility of the business not completely fulfilling its obligations to the state (budget), partners, or employees.

For our analysis, we chose a logit model (Table 5). Logistic regression is widely used to examine and describe the relationship between a binary response variable (e.g., 'success' or 'failure') and a set of predictor variables. We include in our analysis the dummy variable CHOICE, which is equal to " 0 " if retained earnings have a significant negative value and " 1 " if retained earnings are positive for two years, or negative in only one year, or negative values are negligible. Then, the first behavior will allow for non-payment in time salaries (ADD_STAFF), the accumulation of advances (AP_ADV), the non-payment of the insurance sum (AP_INS), and the non-payment of income tax (AP_TAX). And the second behavior will be based on the effective use of inventory accounting methods (result as COGS), amortization politics (result as AMORT_FIX), management encouragement (result as ADM_COST), the expansion of sales markets (result as PURCH_COST) and variation in equity instruments (result as ADD_CAP). In Table 5, we can observe a collaboration of these two behaviors as well as individually. It is worth noting that we consider a business that is not a part of large financial and industrial groups, so it is not possible to attract a nonperforming loan as an instrument. Therefore, it is compelled to seek other lenders or to abandon this type of instrument altogether.

As we can see in Table 5, MODEL 1 shows significantly negative retained earnings, which happens in both approaches (accounting techniques and accounts payables manipulations); MODEL 2 - the results of traditional accounting techniques, MODEL 3 - the result of accounts payables manipulations.

Then, in Table 6, we can predict the results of the group interaction in the case of the coexistence or separate use of instrument compositions, highlighted by the payoff matrix of percentage correct for the two values of the dummy variable choices: "AP" - us- 
ing salaries, insurance, tax, or budget payables as a source of capital; "AT" - using strategic instruments like amortization policy, inventory accounting methods, exchange rates manipulation, or aggressive marketing, etc. According to game theory, the Nash equilibrium is a solution concept of a non-cooperative game which involves a strategical choice when the best decision for one player is at the same the best decision for another.

Table 5. Results of Logit modeling for different strategy choices

\begin{tabular}{|c|c|c|c|c|c|c|}
\hline \multirow{2}{*}{ Variables } & \multicolumn{2}{|c|}{ Model 1} & \multicolumn{2}{|c|}{ Model 2} & \multicolumn{2}{|c|}{ Model 3} \\
\hline & Wald & Sig. & Wald & Sig. & Wald & Sig. \\
\hline COGS & 4.329 & 0.037 & 0.965 & 0.326 & & \\
\hline AMORT_FIX & 3.559 & 0.059 & 0.001 & 0.974 & & \\
\hline ADM_COST & 2.048 & 0.152 & 4.031 & 0.045 & & \\
\hline PURCH_COST & 4.668 & 0.031 & 2.469 & 0.116 & & \\
\hline ADD_CAP & 3.577 & 0.059 & 0.502 & 0.479 & & \\
\hline AP_STAFF & 2.467 & 0.116 & & & 4.193 & 0,041 \\
\hline AP_ADV & 0.100 & 0.751 & & & 2.421 & 0.120 \\
\hline AP_TAX & 1.006 & 0.316 & & & 0.004 & 0.950 \\
\hline AP_INS & 2.625 & 0.105 & & & 1.715 & 0.190 \\
\hline CONSTANT & 2.137 & 0.144 & 3.064 & 0.080 & 2.669 & 0.102 \\
\hline Cox\&Snell $R^{2}$ & \multicolumn{2}{|c|}{0.589} & \multicolumn{2}{|c|}{0.307} & \multicolumn{2}{|c|}{0.391} \\
\hline
\end{tabular}

Source: authors' own research.

Table 6. Best prediction result of the group interaction in the case of the coexistence or separate use of instrument compositions

\begin{tabular}{|l|l|c|c|}
\cline { 3 - 4 } \multicolumn{2}{c|}{} & \multicolumn{2}{c|}{ Behavior 2} \\
\hline \multirow{2}{*}{ Behavior 1 1} & AT as the main instrument & Not AT as the main instrument \\
\cline { 2 - 4 } & Using AP & $96.3 ; 92.3^{*}$ & $92.6 ; 46.2$ \\
\hline
\end{tabular}

Notes: * - percentage correct for the two values of the dummy variable choices: "AP" - using salaries, insurance, tax, or budget payables as source of capital; "AT" - using strategic instruments like amortization policy, inventory accounting methods, exchange rates manipulation, aggressive marketing, etc.

Source: authors' own research.

Table 7. Payoff matrix of the group interaction in the case of the coexistence or separate use of compositions of instruments

\begin{tabular}{|l|l|c|c|}
\cline { 3 - 4 } \multicolumn{2}{c|}{} & \multicolumn{2}{c|}{ Behavior 2} \\
\cline { 3 - 4 } \multicolumn{2}{c|}{} & AT as the main instrument & Not AT as the main instrument \\
\hline \multirow{2}{*}{ Behavior 1 1} & Using AP & $\underline{96.3^{*} ; 7.7}$ & $\underline{92.6} ; \underline{53.8}$ \\
\cline { 2 - 4 } & Don't use AP & $93.1 ; \underline{69.2}$ & $0 ; 0$ \\
\hline
\end{tabular}

Notes: * percentage of the positive pay-offs subject to the choice of a specific behavior model.

Source: authors' own research. 
To demonstrate the payoff matrix, we have to rewrite such a schedule (Table 7), based on the widespread practice of the absence of a problem in long-term loss-making. An attractive position remains being unprofitable, as it makes no sense to demonstrate profitability, and there is nobody to hide the loss-making. There is no endeavor on the investor's positive impression on the market.

As expected, on such types of markets, Ukrainian Nash equilibrium is in the square "choice of first behavior and failure of second behavior" (92.6\% and 53.8\%). Other positions lead the company to non-equilibrium.

\section{Conclusions and final remarks}

Despite the significant differences in the impact of unpaid debt in the states of Eastern and Central Europe, Western Europe and Latin America, we can state its negative nature, as well as the divergence of the economic indicators on which this impact is directed.

According to our results, in the case of Eastern Europe, the banking system generally supports the promotion of exports and economic growth. A positive effect of unpaid debt on export flows was revealed (when ignoring the time lag effects) for the states of Western Europe, which can be explained by the banking corporation model in the EU, as the main scope of the banking sector is to ensure technological growth and export support. The interconnection between bank lending and the share of $R \& D$ investment is of particular interest in this case. In the Latin America region, the influence of the banking sector on export-import flows, as well as the economy as a whole, is even more significant than in European countries.

At the same time, we emphasized that, for example, in Ukraine, fewer than $14 \%$ of enterprises use bank loans. We consider that the solution to the problem is not in the growth of government influence or control, but in the reorganization of existing banking institutions, introducing practices of a decentralized banking system with institutional control from the bottom to the top, and transforming banks from being a "stakeholder" into an economic development tool.

An unexpected case in the Ukrainian practice is that is no point in businesses hiding profit by using accounting methods. Such firms operate partially due to the debt to the whole spectrum of their partners. For such a business, a negative financial result for a long period has no traditional consequence, e.g., bankruptcy. Looking at zombie banking in Ukraine, the functioning of enterprises can be based not only on bank lending, but also on the assistance of partners, the state, or even its own employees, by using salaries, insurance, tax, and budget payables as a source of capital. For Ukraine, this behavior today is in position of the Nash equilibrium. 


\section{References}

Acharya, V.V. and Steffen, S. (2014), Falling short of expectations? Stress-testing the European banking system, CEPS Policy Brief No. 315.

Adalet McGowan, M., Andrews, D. and Millot, V. (2017), The walking dead: zombie firms and productivity performance in OECD countries, OECD Economics Department Working Papers, No. 1372.

Banerjee, R. (2018), The rise of zombie firms: causes and consequences, https://www.bis. org/publ/qtrpdf/r_qt1809g.pdf (accessed: 15.02.2019).

Borio, C., Gambacorta, L. and Hofmann, B. (2017), The influence of monetary policy on bank profitability, "International Finance", 20 (1), pp. 48-63, https://doi. org/10.1111/infi.12104.

Bush, S. (2018), Zombie Banks and Bank Bailouts, https://owlcation.com/social-sciences/Do-Zombie-Banks-Really-Exist (accessed: 17.02.2019).

Bülbül, D., Schmidt, R.H. and Schüwer, U. (2013), Savings Banks and Cooperative Banks in Europe, Goethe University, Frankfurt.

Constâncio, V. (2016), Challenges for the European banking industry, Lecture at the Conference on "European Banking Industry: what's next?", organised by the University of Navarra, Madrid, 7 July 2016, https://www.bis.org/review/r1607014b.pdf (accessed: 17.02.2019).

Henselmann, K., Ditter, D. and Lupp, P. (2016), The effects of the financial crisis on cooperative banks in Europe - A critical comparison, Working Papers in Accounting Valuation Auditing, https://www.econstor.eu/handle/10419/161671 (accessed: 1.03.2019).

Interfax (2018), Share of non-performing loans in Ukraine decreases to 56.09\% in May, https://en.interfax.com.ua/news/economic/514728.html (accessed: 5.03.2019).

Investopedia (2018), Zombie Bank, https:/www.investopedia.com/terms/z/zombie-bank.asp (accessed: 25.02.2019).

Kanaya, A. and Woo, D. (2000), The Japanese banking crisis of the 1990s: sources and lessons for Japan, "Journal of Financial Economics", 97 (3), pp. 398-417.

Kawai, M. (2005), Reform of the Japanese banking system, "International Economics and European Policy", 2 (4), pp. 307-335.

Lacalle, D. (2017), The Rise of Zombie Companies - And Why It Matters, https://mises. org/ library/rise-zombie-companies-\%E2\%80\%94-and-why-it-matters-0 (accessed: 15.02.2019).

Markevičius, J. (2017), European banks must weed out bad loans to avoid zombie banks, https://www.lb.lt/en/news/j-markevicius-european-banks-must-weed-out-bad-loa ns-to-avoid-zombie-banks (accessed: 21.01.2019).

Ministry of Finance of Ukraine (2018), https://www.minfin.gov.ua/en/news/borg (accessed: 20.01.2019).

Mora, M. (2017), Dealing with non-performing loans. European versus Czech Perspective, "Financial Stability Seminar", $11^{\text {th }}$ Edition, Bucharest.

Nakaso, H. (2001), The financial crisis in Japan during the 1990s: how the bank of Japan responded and lessons learn, Bank International Settlements, BIS Papers No. 6. 
Ostrom, E. (1990), Governing the commons. The evolution of institutions for collective action, Cambridge University Press, Cambridge.

Quiggin, J. (2012), Zombie Economics, https://eldivandenerdas.files.wordpress. com/2011/12/ zombie-economics.pdf (accessed: 15.01.2019).

Radivojevic, N. and Jovovic, J. (2017), Examining of determinants of non-performing loans, "Prague Economic Papers", 26 (3), pp. 300-316.

Schnabl, G. (2013), The macroeconomic policy challenges of balance sheet recession: lessons from Japan for European crisis, CESifo Working Paper 4249, CESifo.

Schoenmaker, D. \& Peek, T. (2014), The state of the banking sector in Europe, Economics Department Working Papers 1102, OECD.

The Global Economy, Ukrainian Financial Forum, Ukraine: Small firms with bank credit, https://www.theglobaleconomy.com/Ukraine/small_firms_bank_credit/ (accessed: 23.01.2019).

The World Bank data, Bank nonperforming loans to total gross loans (\%), https://data. worldbank.org/indicator/FB.AST.NPER.ZS?type=shaded\&view=map (accessed: 30.01.2019).

Willam, D. (2015), Zombie banks and forbearance lending: causes, effects, and policy measures: dissertation, Cologne: Leipzig University, http://www.qucosa.de/fileadmin/data/qucosa/documents/15955/DissertationPublicationFinal.pdf (accessed: 12.02.2019).

\section{Streszczenie}

\section{Zjawisko zombie w bankowości i biznesie - analiza porównawcza oraz instytucjonalne podłoże problemu}

W artykule przedstawiono zjawisko zombie w bankowości i biznesie. Główne cele publikacji to: wyjaśnienie negatywnych konsekwencji w przypadku niespłacalnych pożyczek dla państw Europy Środkowo-Wschodniej, Europy Zachodniej, Ameryki Łacińskiej oraz grupy byłych państw ZSRR oraz przedstawienie zjawiska firm zombie w przypadku Ukrainy, w tym ujawnienie nowej formy zombie biznesu na podstawie narzędzi pozabankowych. Autorzy twierdzą, że rozwiązaniem problemu zombie banków nie jest kontrola państwa, lecz restrukturyzacja systemu bankowego oparta na zdecentralizowanym i silnie kontrolowanym modelu oddolnym. Poza tym nieefektywność systemu instytucjonalnego generuje różne formy zombie biznesu. Przypadek Ukrainy jest doskonałą ilustracją narzędzi pozabankowych stosowanych w zombie biznesie. Artykuł podkreśla wpływ nierentownych kredytów na gospodarkę oraz perspektywy tworzenia systemu bankowego w świetle instytucjonalnym i interakcji międzyinstytucjonalnych przy aktywnym udziale niespłacalnych kredytów.

Słowa kluczowe: system bankowy, bankowość, banki zombie, zombie biznes, niespłacalne pożyczki, teoria instytucjonalna 